\title{
Chapter 10 \\ Childlessness and Fertility Dynamics of Female Higher Education Graduates in Germany
}

\author{
Hildegard Schaeper, Michael Grotheer, and Gesche Brandt
}

\subsection{Introduction}

This paper examines the process of family formation, defined as the birth of the first child, of female higher education graduates belonging to different graduate cohorts. Focusing on this particular population allows us to take a closer look at a phenomenon which, although known to exist for some time, has only recently started to receive significant attention in the media and in research: namely, the declining and low birth rates among women with a higher education degree.

For a long time, exact figures for Germany on the proportion of female graduates who were permanently childless were not available. The number of actual births among this group was first recorded by the microcensus of 2008 , which provides a more accurate picture of childlessness among women than was previously available (Pötzsch 2010). Analyses of these data have concluded that the share of female graduates who are childless is $29.5 \%$, and far higher than the $19.5 \%$ share among other women. There is little indication that this difference is chiefly attributable to a lower desire for children among university graduates. Although there is some evidence suggesting that female higher education graduates are slightly less likely than women with lower educational levels to want children (Dorbritz and Ruckdeschel 2013), and that they have a tendency to subordinate this desire to other aspirations (Passet 2011), women of different educational levels vary much less in their desire to have children than in their actual childbearing. In other words, the gap between

\footnotetext{
The more detailed German version of this paper was published under the title "Familiengründung von Hochschulabsolventinnen. Eine empirische Untersuchung verschiedener Examenskohorten" (Schaeper et al. 2013).

H. Schaeper $(\bowtie) \bullet$ M. Grotheer $\bullet$ G. Brandt

German Centre for Higher Education Research and Science Studies, Deutsches Zentrum

für Hochschul- und Wissenschaftsforschung (DHZW), Hanover, Germany

e-mail: schaeper@dzhw.eu; grotheer@dzhw.eu; g.brandt@dzhw.eu
} 
desire and reality is especially large among highly educated women (Eckhard and Klein 2012).

Both theoretical analyses and empirical studies have pointed out a number of factors which explain why large shares of German women are failing to realise their desire to have children, e.g., the lack of childcare options (especially in western Germany), the lack of a partner (especially among highly qualified women), and the growing significance of paid employment. Whereas in the past a woman's life course tended to be organised predominantly around the family, the social institutions central to the typical female life course now also include career and the labour market. Decisions in one of these spheres are not made in isolation, but depend on developments, decisions, aspirations, and structures in the other sphere.

Thus, in this paper we investigate how and to what extent employment and the labour market affect the transition to motherhood among higher education graduates. Based on theoretical considerations presented in Sect. 10.2, we examine these questions empirically using the graduate studies undertaken by the German Centre for Higher Education Research and Science Studies (DZHW). In Sect. 10.3, we provide further information on these datasets and on the applied statistical methods and variables. The results of the empirical analyses are presented in two parts in Sect. 10.4. First, we examine the process of family formation from the age of 14 onwards. Second, we examine in detail the relationship between occupational career and family formation, focusing exclusively on the period after the first degree was awarded.

\subsection{Theoretical Basis}

\subsubsection{General Theoretical Assumptions from a Life Course Perspective}

The analysis of the transition to motherhood is based on life course theory. According to this perspective, actions which are biographically significant and associated with status changes are, like all actions, embedded in the life course and have multiple time references. Such actions take place in the present and are shaped by the current context. But they also refer both subjectively ("in-order-to motives", Schütz 1971: 80) and objectively (intended and unintended consequences) to the future, and in particular to the past: i.e., to biographical experiences, accumulated resources, and decisions and circumstances of the preceding life history. These factors shape biographies and subjectively prompt action ("because motives", ibid.).

From a diachronous perspective, the life course resembles a sequence of events, states, or status passages. However, in view of the multidimensional nature of life courses or their synchronous integration in several life domains, it is more appropriate to follow René Levy's (1996: 73) conceptualisation of the life course as a "sequence of participation-position-role configurations." Assuming further that 
developments in various areas of life are interdependent (Huinink 1995: 154), family formation can be regarded as a process which depends on the woman's occupational career, as well as other factors, such as her educational and union history.

Furthermore, the life course is part of a social multi-level process (Huinink 1995: 154-155). The actors are situated at the micro level, where they act in relation to their individual, but nonetheless collectively shaped aspirations and preferences; as well as in response to the prevailing opportunities and restrictions. The conceptualisation of these actions as rational-i.e., driven by cost-benefit deliberations and the objective of maximising utility - has become a dominant paradigm in analyses and explanations of fertility decisions. Empirical studies have indicated that the model of rational action has, indeed, a role to play in explaining behaviour (Schaeper and Kühn 2000) and that especially among female graduates family formation is to a large extent the result of a deliberate process of planning, decision-making, and evaluation (Herlyn et al. 2002). In this process, women weigh not only the direct economic costs and the psychological costs (e.g., stress, emotional burdens) of having children, but also the indirect (opportunity) costs, which are related to the forgone benefits of alternative uses of time (e.g., time spent in employment). Women may also consider the benefits of having children: While in modern societies children are seldom seen as sources of income or old-age insurance, they are especially thought to provide psychological and emotional benefits (e.g., personal fulfilment, life enrichment, affection).

When choosing a course of action, individuals refer to their immediate social context; i.e., to partners, peers, and members of their family of origin. This implies, for example, that actors are required to coordinate their life course, decisions, and plans with those of other people ("linked lives"). Furthermore, the individual's actions are embedded in a regional context which provides a variety of opportunity structures (e.g., labour market opportunities, childcare options) and socio-cultural orientation patterns. Finally, actions are framed by the structural and cultural conditions of the society through generally applicable opportunity structures, overarching norms, and interpretive schemes; as well as through largely binding institutions, such as school/university, labour market/occupation, and family.

\subsubsection{Specific Assumptions About the Transition to Motherhood Among Female Higher Education Graduates}

The effects of general structural and cultural changes on the timing of family formation and the extent of childlessness are usually assessed by taking the birth year as a proxy variable. Several studies (e.g., Blossfeld and Rohwer 1995) have demonstrated that the transition to motherhood was taking place at progressively higher average ages among women born after the middle of the twentieth century. Accordingly, we would also expect a trend towards fertility postponement among 
higher education graduates. However, the graduate cohorts included in our study represent only a relatively short historical period. Furthermore, Blossfeld and Rohwer (1995) found that the cohort effect disappears entirely if educational participation is controlled for. Given the brevity of the historical observation window and the small degree of variability in terms of both the participation in and the duration of education among the graduate cohorts studied, we expect to see only slight cohort differences.

The studies which have investigated the influence of participation in education on family formation have all found that the transition to motherhood is unlikely to take place as long as the prospective mother is in education (e.g., Blossfeld and Rohwer 1995; Schröder and Brüderl 2008; Buhr et al. 2011; Maul 2012). Research has shown that since 1991 the share of higher education students who have children has been around 6-7\% (Middendorff 2008). There are two main reasons why so few students have children. First, because of insufficient economic resources family formation during education appears to be inopportune (Huinink 1995). Second, most young people do not occupy themselves with family-related questions while in education, as they are concentrating on education-related biographical tasks (ibid.). If students give any thought to such matters, they generally associate family formation with high opportunity costs and competing demands on their time. Education calls for a large investment of time, and is therefore difficult to reconcile with family commitments (ibid.). Students who have children, and especially female students, can expect to take longer to complete their education, or may even be forced to drop out (Middendorff 2008; Heublein et al. 2010). As dropping out of education can have far-reaching negative implications for an individual's future income and career opportunities, having children while in education can give rise to high indirect costs.

These general observations apply to the social conditions prevailing in the Federal Republic of Germany (FRG). We therefore expect to find a significantly reduced inclination towards childbearing during the period of study among both western German respondents and eastern German study participants of the more recent cohorts. It should be noted, however, that the policies of the German Democratic Republic (GDR) attenuated the resource, compatibility, and prospects problems, and, according to Huinink (2000: 216), may have even incentivised starting a family early. In the GDR, several measures were specifically designed to support female students with children. In addition, the financial burdens of supporting a child in the GDR were negligible given the low cost of living, the availability of affordable childcare and housing, and the financial security provided by scholarships, which were augmented by a child benefit (Leszczensky and Filaretow 1990). For these reasons, we can expect to find that the institution effect was much less pronounced among eastern German female higher education graduates who belong to earlier graduate cohorts and began their studies before 1990 or shortly thereafter than among their western German counterparts.

Comparisons of the family formation process and family forms in eastern and western Germany clearly illustrate that significant differences persist, even though alignment processes are taking place in many spheres (Goldstein et al. 2010). A larger proportion of eastern German than western German women have children, 
and easterners tend to make the transition to motherhood earlier than westerners (Buhr et al. 2011). However, the proportions of childless women who do not wish to become mothers, and perceptions concerning the ideal family size, have started to converge between east and west (ibid. 187). We therefore assume to find persisting differences, but also increasing similarities between the family formation behaviour of women of the more recent eastern German graduate cohorts and those of their western German counterparts.

Our hypothesis that behaviour patterns are converging is based on the fact that after German reunification, the "gender order" (Pfau-Effinger 1998) and institutional environment of western Germany were introduced in eastern Germany, implying a "structural incompatibility" or, at best, "sequential compatibility" of family and career (Dornseiff and Sackmann 2003). The hypothesis of the enduring difference is supported by the persistence of a specifically eastern German "gender culture". According to the prevailing role model of the "working housewife and mother", for example, a woman was expected to be in continuous full-time employment, with only brief interruptions for family leave, while simultaneously maintaining her traditional responsibilities in the home. The transfer of the western German gender order gave rise to a cultural lag in eastern Germany; i.e., the gender culture lagged behind structural change. According to the literature cited by Maul (2012), the "cultural heritage" of the GDR continues to exert an influence up to today.

For western Germany as well, we can assume that the cultural and social structures did not develop in parallel. The FRG's organisations and institutions of the welfare state, the labour market, and the family have long lagged behind the modern paradigm of womanhood - which is oriented towards independence, employment, and a "double conduct of life" (Pfau-Effinger 1998; Born 2001). This "structural lag" and corresponding "compatibility dilemma" especially applied to welleducated western German women with high career ambitions who consider the usual models for reconciling work and family life, such as taking career breaks and moving to part-time work, as being hardly compatible with their aspirations.

Because of this compatibility issue we can expect to find that a woman may postpone the decision about whether to have a family until the time-consuming process of establishing and consolidating a career, which calls for flexibility and mobility, has been completed; and that this postponement can easily lead to unintended or deliberate childlessness. In view of the resource problem and the problem of prospects, we, in addition, can assume that for a highly educated woman, having a stable and sustainable professional position may be seen as a prerequisite for making the transition to motherhood. We would therefore expect to find, for example, that having a permanent employment contract would positively influence the inclination to form a family. However, the results of empirical studies examining this hypothesis, which is based on educationally diverse samples, is ambiguous. Schmitt (2008) found on the basis of data from the German Socio-Economic Panel (GSOEP) that fixed-term contracts have a negative effect on the entry into motherhood. The analyses of Gebel and Giesecke (2009), on the other hand, indicated that having a temporary employment contract does not have an impact on the transition to 
parenthood for either men or women; and Brose (2008) came to the same conclusion for women only.

However, according to the theory of the value of children proposed by Friedman et al. (1994), insecurity or a lack of certainty concerning biographical prospects can also have the opposite effect. To reduce uncertainty, women whose chances of having a stable professional career are poor could have children earlier and more frequently. This assumption is substantiated in family economics by the argument that, for women with diminished career resources, the opportunity costs associated with motherhood-i.e., the temporary loss of earnings and the long-term detrimental impact on a career and social security — are relatively low. Both arguments imply that a mismatch between occupational position and education, or the experience of downward occupational mobility, tends to accelerate family formation; and that having full-time gainful employment and an elevated professional position tends to delay the transition to motherhood. It is, however, possible that the influence of biographical prospects differs depending on educational attainment. Kreyenfeld (2010) found, for instance, that perceiving the economic situation to be uncertain and having concerns about job security has negative effects on family formation among women with high levels of education, but positive effects among women with lower levels of education.

Women's orientations regarding family and career generally are not directly included in quantitative analyses because they are rarely measured before the start of the process being examined. In many cases, researchers can use only rough indicators which are known to correlate with the phenomenon of interest, such as social origin (see below), religious affiliation, educational attainment, or subject area. A number of studies (e.g. Heine et al. 2005) have, for example, found that students who pursue a degree in medicine or teaching tend to have a strong social orientation and relatively weak career ambitions; whereas students who study law, business, or economics tend to be highly materialistic and career-oriented. At the same time, different types of degrees open up different career opportunities. These observations suggest that family formation rates among graduates in different disciplines are likely to vary considerably. Indeed, research conducted in other countries has shown that the field of study is a better predictor of fertility behaviour than the level of education (Neyer et al. in this volume). In light of sometimes competing theoretical arguments and opposing effects of career orientations and resources in some fields of study, it is difficult to put forward a hypothesis regarding the direction of the differences.

Occupational careers continue to be influenced by social origin, irrespective of the level of qualification attained. With respect to higher education graduates, studies have shown (e.g. Hemsing 2001) that parents' social status and education not only have an indirect effect on career success of their children (resulting from the association between choice of subject, higher education institution and social origin); they also have a direct, independent effect. In addition, the social position of the family of origin exerts an influence on the children's career orientation, aspirations, and expectations. We can therefore assume-in line with previous studies 
(Blossfeld and Rohwer 1995) — that graduates whose parents have a high social position are more likely than others to postpone family formation.

In recent years, a series of policy measures have been introduced which were designed to alleviate the resource, incompatibility and prospects problems, and thus to increase the birth rate. However, the impact of these policies may take one to two decades to become apparent (Bujard 2011: 37). We therefore do not expect to observe an effect of these measures on the cohorts of female graduates who are the subject of the present study.

\subsection{Data and Methods}

\subsubsection{Data}

The analyses of the family formation process among female higher education graduates are based on the panel studies of higher education graduates conducted by the German Centre for Research on Higher Education and Science Studies (Deutsches Zentrum für Hochschul- und Wissenschaftsforschung, DZHW). The DZHW graduate studies cover the entire range of subjects, and include all state-run and stateapproved higher education institutions, with minor exceptions.

The survey programme currently spans six graduate cohorts with up to three panel waves. In the survey of the 1989 cohort (who graduated in winter semester 1988/1989 or summer semester 1989 from a higher education institution in the preunification territory of the Federal Republic of Germany), 2898 women were observed over an average period of 42 months after graduation. The survey of the 1993 cohort, which for the first time included graduates from eastern Germany, yielded data of 2617 women for an average period of 66 months after graduation. In the surveys of the 1997, 2001 and 2005 cohort, 2739 respectively 3307 and 3828 women were observed over an average period of 70 months after graduation. Finally, in the first and only survey to date of the 2009 cohort, 2980 female graduates who completed a bachelor's degree course were surveyed alongside 3418 female graduates who attended traditional courses which concluded with either a state examination, a Diplom degree, or a Magister degree. The observation period of this cohort covers an average of 14 months after graduation.

\subsubsection{Approach and Method}

In order to obtain a descriptive overview of the process concerned, the survival functions for all of the graduate cohorts were estimated using the Kaplan-Meier method. The multivariate analyses used techniques of event history analysis. We estimated exponential models assuming a constant rate over time. The 
time-dependence of the processes being analysed was taken into account by integrating time-varying covariates (such as current age and educational participation). First, we estimated separate models for eastern Germany and western Germany. Second, we tested the east-west effect in a joint model. All of the results presented here were preceded by a comprehensive examination of theoretically possible interaction effects. In the interests of parsimony and simplicity, only significant interaction effects were included in the final models. Since the DZHW surveys consist in part of disproportionately stratified random samples of graduates, the analyses were performed with Stata statistical software using sampling weights.

\subsubsection{Model Specification}

Two perspectives are adopted in the analysis of the transition to motherhood. The first strand of analysis looks at all of the graduate cohorts and examines the transition to motherhood from the age of 14 onwards. The process time is therefore the age of the woman. Because of their particular biographies, graduates who belonged to older birth cohorts (pre-1960 cohorts in the west and pre-1965 cohorts in the east) or who qualified for entry into higher education abroad were disregarded. After application of these selection criteria, the sample for the survival analyses consists of 16,233 western German and 3835 eastern German women. The following variables were included in the multivariate models:

Graduate Cohort For the most part, the graduate cohorts correspond to specific birth cohorts. In the vast majority of cases, the women in the 1989 graduate cohort were born between 1960 and 1964, and the women in the 1993 graduate cohort were born between 1965 and 1969. However, the subsequent graduate cohorts are somewhat less homogeneous in age. The 2009 cohort also includes graduates of the new, shorter bachelor's degree programmes. These bachelor's degree graduates are on average 2 years younger than the graduates of traditional degree courses. For reasons which will be explained later, the results for the 1989 and 2009 graduates are reported in the survival analyses only.

Participation in Education We use two indicators for measuring the effect of being in education: (1) the annually adjusted time-dependent variable "studying for a first degree" (labelled "in first degree course"), which assumes the value one for as long as the respondents meet this criterion (and the value zero upon completion of the first degree); and (2) the annually adjusted time-varying variable "pursuing further higher or professional education (after having completed the first degree)" (labelled "in further education"). Because the effects did not differ, studying for a doctoral degree, studying for a second degree, and participating in professional training were grouped together in this variable. 
Subject of First Degree and Degree Type For the type of degree, university degrees are distinguished from degrees awarded by universities of applied sciences. For the subject or field of study, three groups are distinguished: (1) social work (universities of applied sciences), teaching, and human medicine; (2) law, business, and economics; and (3) all other subjects.

Parents' Education This variable is defined as the educational attainment of the higher status parent. It is represented by three dummy variables: (1) lower secondary school leaving certificate/no school leaving certificate; (2) intermediate school leaving certificate/higher education entrance qualification; and (3) higher education degree.

Regional Origin Women graduates who obtained their higher education entrance qualification in the western German federal states are compared with their counterparts from the eastern German states.

Age To control for the well-known non-monotonic, bell-shaped age dependence of the rates of entry into first motherhood, two time-varying age variables- $\log$ (current age-13) and $\log (45$-current age) - are included.

The method of episode splitting is used to introduce time-varying covariates into the model. The process time is measured in annual intervals only, and the age variables are adjusted annually. The imprecise measurement of the process time may give rise to an underestimation of the events in the right-censored survey years. For this reason, the models of the first strand of analysis are estimated for the 1993, 1997, 2001, and 2005 cohorts only, as their observation windows are of similar length (number of cases: 9074 western German and 2284 eastern German female respondents providing data for all variables).

The second strand of analysis looks at higher education graduates of the years 1997, 2001, and 2005 who were childless when they finished their studies, and who were born after 1960 for western German women or after 1965 for eastern German women (number of cases: 6470 western German and 1866 eastern German study participants with complete data). The subject of this analysis is the transition to motherhood after graduation, with a focus on the impact of career development and employment situation. In this case, therefore, the process time starts with graduation, and is recorded on a monthly basis. The cohort 1989 and 1993 had to be excluded from the analyses because the questionnaires addressed only the current employment situation. The 2009 cohort was excluded because the observation window of 14 months was too short to allow us to adequately examine the influence exerted by the graduates' employment history and employment situation.

Career progression and the employment situation are represented by the following characteristics:

Economic Inactivity (time-dependent), which is contrasted with economic activity and takes on different values: (1) periods of economic inactivity before starting the first job or commencing further training or education ("transitional phase"), (2) 
further higher or professional education (further training phases, studying for a doctorate or second degree; labelled "further education"), (3) other periods of economic inactivity lasting no more than 3 months ("interruption of up to 3 months"), and (4) other periods of economic inactivity lasting more than 3 months ("interruption of more than 3 months"). Women in gainful employment who were simultaneously participating in education are deemed to be economically inactive during such periods; those who are formally participating in an apprenticeship or an internship were likewise classified as economically inactive.

Education-Job Mismatch at Labour Market Entry (time-constant variable "negative start"), which is given when the first employment position after graduation clearly had a lower status than is warranted by the graduate's educational qualifications (e.g., unpaid family worker; unskilled, semi-skilled, or skilled worker; lower or middle-grade civil servant; low-level employee).

\section{Length of Time Between Graduation and First Permanent Employment}

Contract (time-constant variable "permanent contract"), for which we distinguish four categories: (1) no permanent contract throughout the entire observation period, (2) first permanent contract obtained in the first 12 months after completion of studies, (3) first permanent contract obtained in the second or third year after graduation, and (4) first permanent contract obtained at a later date.

Self-Employment (time-constant) with two categories: never self-employed, and self-employed at least once during the observation period. ${ }^{1}$

Full-Time Gainful Employment (time-varying), contrasted with part-time employment.

Career Development (time-varying), for which we distinguish between lateral career paths, upward mobility, downward mobility, and discontinuous career patterns. Career development is reconstructed by arranging the employment positions in a hierarchical order: Unpaid family workers; unskilled and semi-skilled workers (Level 1), skilled workers, lower and middle-grade civil servants, low-level employees (Level 2), skilled employees, self-employed individuals with a contract for services/fee contract (Level 3), academically qualified employees without managerial responsibility, high-grade civil servants (Level 4), academically qualified professional employees with intermediate managerial responsibility, self-employed professionals, senior civil servants (Level 5), executive employees, independent entrepreneurs (Level 6).

\footnotetext{
${ }^{1}$ Self-employment (excluding contracts for work and services and fee contracts) ranks among the types of employment which - at least during the initial period—entail a certain degree of biographical uncertainty, and which are, as a rule, very time-consuming. It is to be assumed that this time pressure also applies in periods preceding, and during interruptions of, self-employment. The self-employment variable was therefore included as a time-constant characteristic.
} 
Upward and Downward Mobility are defined as a job change that was accompanied by an increase or a decrease in rank or position. The initial attainment of a higher ranking position following a mismatch between educational qualification and job status at the time of labour market entry is not, however, classified as an upward move. The time-varying dummy variables retained the value one if the first upward move (downward move) is followed by a second upward move (downward move), or the professional position is no longer subject to change. If a downward move was followed by a step up the career ladder, or an upward move was followed by a downward move, the career was thereafter deemed to be erratic; the variables "upward/downward move" and "downward/upward move" are coded one, irrespective of the subsequent career development. Lateral career paths are therefore employment histories with neither upward nor downward moves.

Employment Position (time-varying) based on the results of estimates using the multi-level ranking of occupational positions and for the sake of a clear presentation of results, a distinction is made between only two aggregated categories: the extreme levels 1, 2, and 6; and the intermediate ranks on the career ladder (levels 3, 4, and 5; compare the career levels described above).

Region of Work (time-varying). This variable distinguishes between the western German states, the eastern German states, and other countries.

Work Experience This control variable has to be included to ensure that for all timeconstant variables of the employment history, the reference category consisted exclusively of women who were economically active at least once in the observation period.

\section{Graduate Cohort, Subject Area and Type of Degree, Parents' Education, Age and Regional Origin These variables are constructed as described above.}

All of the covariates of the employment history and career path that are designed as time-varying characteristics are adjusted on a monthly basis. Since the focus of the analysis of the transition to motherhood is on the moment of decision-making, consideration is given not to the graduate's current employment situation, but to the situation 9 months earlier.

\subsection{Empirical Findings on the Transition to Motherhood of Higher Education Graduates}

\subsubsection{Family Formation in Different Cohorts}

Figure 10.1 depicts the survival functions for different graduate cohorts, which provide information on the probability of the graduates remaining childless up to a given age. The graph reveals that there are relatively small differences between cohorts of western German female graduates. However, these differences become 


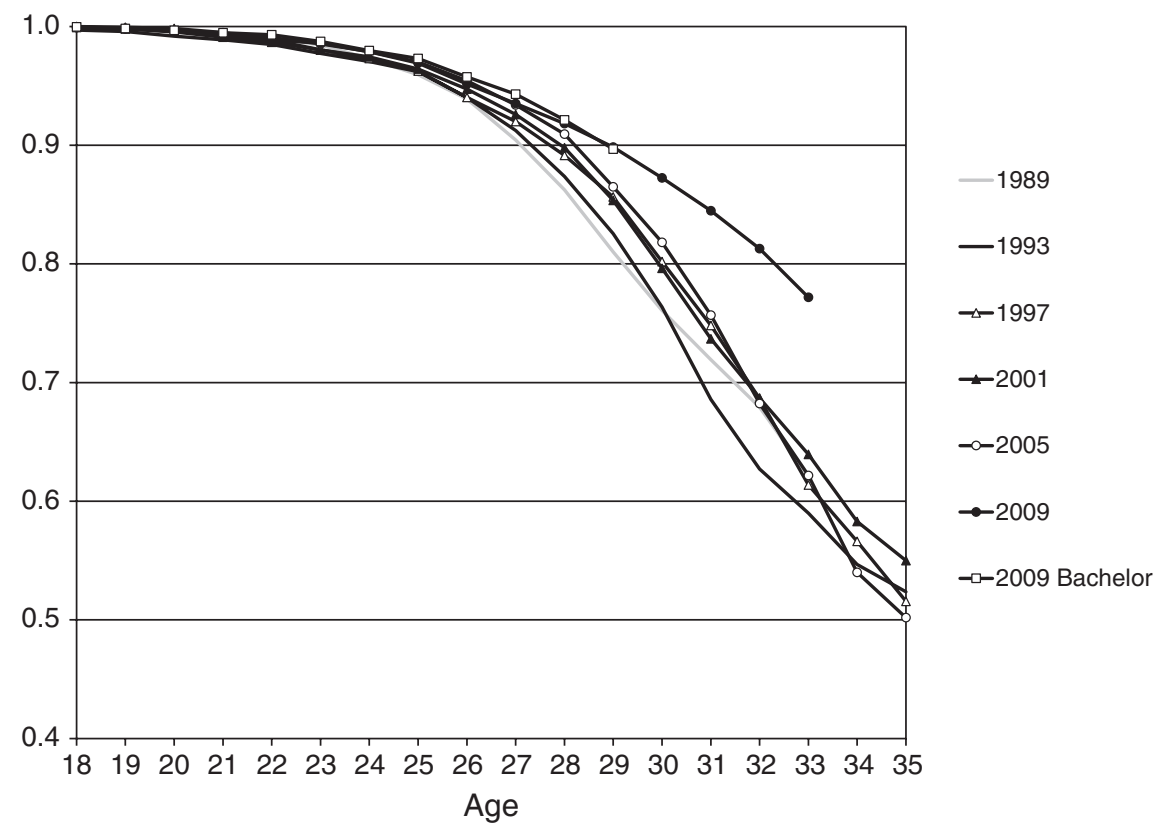

Fig. 10.1 The transition to motherhood of western German higher education graduates in different graduation cohorts (Kaplan-Meier survival function) (Source: DZHW graduate surveys 1989-2009)

pronounced for the 1997 cohort onwards. Almost $25 \%$ of the "quickest" graduate cohorts-namely, those of 1989 and 1993, for whom the survival functions do not differ significantly — had made the transition to motherhood up to the age of 30 , and almost $40 \%$ (1993 cohort) up to the age of 32. In the subsequent graduate cohorts, childbearing was increasingly delayed. In the cohorts 1997, 2001, and 2005, only around $20 \%$ of the women had given birth to a child at the age of 30, and only around $30 \%$ had made the transition to motherhood at the age of 32 (measured against the 1993 cohort, the differences are significant with an error probability of less than .05). The significantly delayed family formation of western German women who graduated from a traditional degree programme in 2009 is particularly striking. An estimated $80 \%$ of them were still childless at the age of 32 . We can assume, however, that the differences will be reduced once the observation period for the 2009 cohort more or less matches those currently available for the older cohorts. ${ }^{2}$ In the 2009 cohort, no differences can be observed between western

\footnotetext{
${ }^{2}$ Given the imprecise process time, events which took place at the time of the survey (i.e., at rightcensored ages) are underestimated. The second panel waves have shown that, at the ages which were right-censored at the time of the first survey, a series of further events (births) occurred. In addition, the number of births increased sharply in the observation period of the second panel waves. Since the 2009 cohort has been surveyed only once thus far, this means that, for instance, women who were 30 years old at the time of the first survey 1 year after graduation (2009 cohort)
} 
German graduates with a traditional degree and with a bachelor's degree, despite the fact that the majority of women who earned a bachelor's degree subsequently undertook a further period of study.

The trend towards fertility postponement was stronger among higher education graduates in the eastern German states than among their western German counterparts (Fig. 10.2). Only the differences between the 2001 and 2005 cohorts are insignificant. It follows from this finding that, as expected, the first birth rates of eastern and western German graduates are becoming more similar. The changes which took place between the 1993 and 1997 cohorts are striking. Between these two cohorts the probability of giving birth to a first child by the age of 27 dropped from more than $30 \%$ to $20 \%$. Between the 1997 and 2001 graduate cohorts, a further reduction of six percentage points can be observed. Despite the convergence of cohorts, the east-west differences within cohorts were highly significant for all cohorts. Among the eastern German bachelor's degree graduates in the 2009 cohort, who are even more likely than their western German counterparts to have undertaken a second course of study, family formation was a rare event in the observation period.

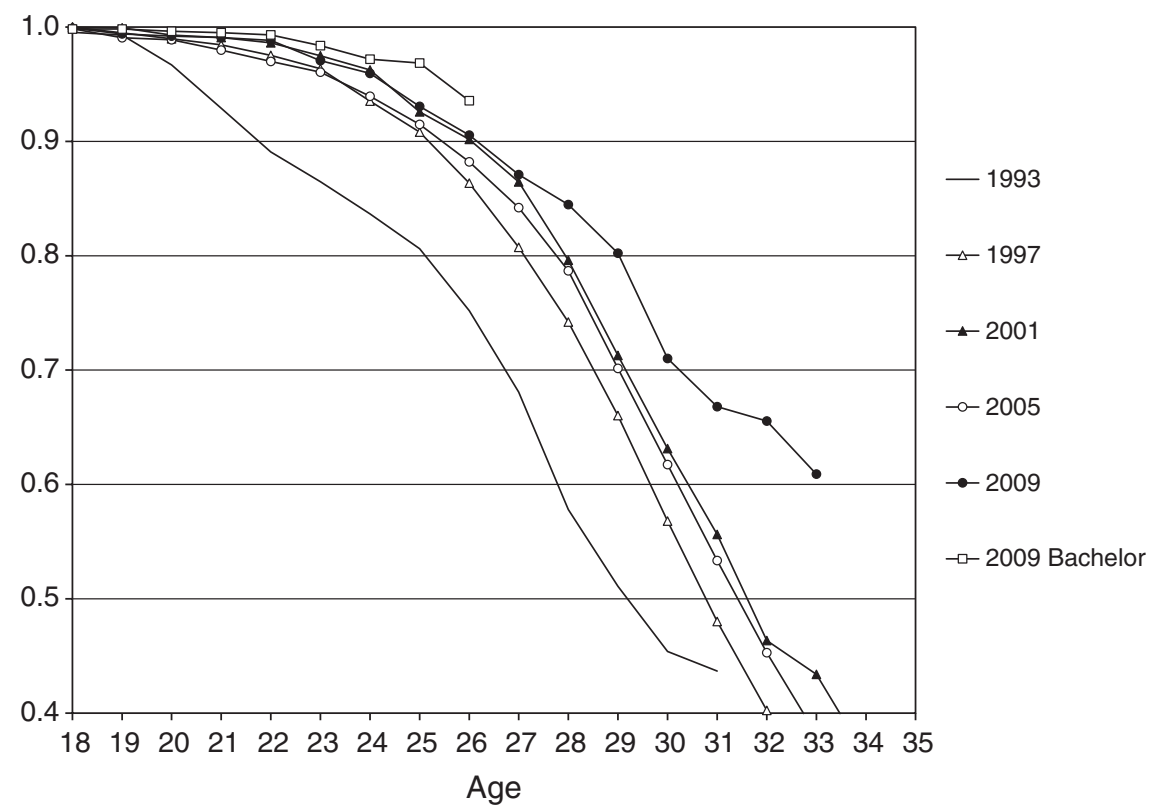

Fig. 10.2 The transition to motherhood of eastern German higher education graduates in different graduation cohorts (Kaplan-Meier survival function) (Source: DZHW graduate surveys 1993-2009)

had given birth to fewer children to date than women who were 30 years old at the time of the second survey 5 years after graduation (other cohorts). These considerations also apply, albeit to a lesser extent, to the 1989 cohort (average observation window of three and a half years). In view of these data artifacts, the 1989 and 2009 cohort were excluded from the multivariate models. 
Table 10.1 The transition to motherhood of higher education graduates in different cohorts (exponential rate models), beta coefficients

\begin{tabular}{|c|c|c|c|c|c|c|c|c|}
\hline \multirow{2}{*}{ Graduate cohort (ref.: 1993) } & \multicolumn{2}{|l|}{$\begin{array}{l}\text { Western } \\
\text { Germany } \\
\text { Model I }\end{array}$} & \multicolumn{2}{|l|}{$\begin{array}{l}\text { Eastern } \\
\text { Germany } \\
\text { Model II }\end{array}$} & \multicolumn{2}{|c|}{$\begin{array}{l}\text { Combined } \\
\text { Model III }\end{array}$} & \multicolumn{2}{|c|}{$\begin{array}{l}\text { Combined } \\
\text { Model IV }\end{array}$} \\
\hline & & & & & & & & \\
\hline 1997 & -0.09 & & -0.01 & & -0.12 & $*$ & -0.09 & \\
\hline 2001 & -0.15 & $*$ & -0.24 & & -0.19 & $* *$ & -0.18 & $* *$ \\
\hline 2005 & -0.15 & $*$ & -0.15 & & -0.17 & $* *$ & -0.16 & $* *$ \\
\hline $\begin{array}{l}\text { In first degree course }{ }^{\text {a }} \text { ref.: } \\
\text { no) }\end{array}$ & -0.67 & $* *$ & -1.09 & $* *$ & & & -0.72 & $* *$ \\
\hline $\begin{array}{l}\text { In first degree } \text { course }^{\mathrm{a}} \times \\
\text { cohort } 1993\end{array}$ & -0.11 & & 1.24 & $* *$ & & & & \\
\hline $\begin{array}{l}\text { In first degree } \text { course }^{\mathrm{a}} \times \text { east } \\
\times \text { cohort } 1993\end{array}$ & & & & & & & 1.19 & $* *$ \\
\hline $\begin{array}{l}\text { In first degree course }{ }^{\mathrm{a}} \times \text { law/ } \\
\text { business/economics }\end{array}$ & -0.58 & $* *$ & 0.41 & & & & -0.32 & \\
\hline $\begin{array}{l}\text { In further education }{ }^{\mathrm{a}} \text { (ref.: } \\
\text { no) }\end{array}$ & -0.47 & $* *$ & -0.35 & $* *$ & & & -0.44 & $* *$ \\
\hline \multicolumn{9}{|c|}{ Subject of first degree (ref.: other subjects) } \\
\hline $\begin{array}{l}\text { Teaching/medicine/social } \\
\text { work (univ. of appl. sciences) }\end{array}$ & 0.43 & $* *$ & 0.32 & $* *$ & & & 0.40 & $* *$ \\
\hline Law/business/economics & -0.06 & & -0.29 & $*$ & & & -0.11 & \\
\hline $\begin{array}{l}\text { University degree (ref.: } \\
\text { awarded by univ. of appl. sc.) }\end{array}$ & -0.05 & & 0.27 & $* *$ & & & -0.05 & \\
\hline University degree $\times$ east & & & & & & & 0.34 & $*$ \\
\hline \multicolumn{9}{|c|}{ Parents' education (ref.: lower secondary school leaving cert./no school leaving cert.) } \\
\hline $\begin{array}{l}\text { Intermediate school leaving } \\
\text { cert./Higher education } \\
\text { entrance qualification }\end{array}$ & -0.06 & & 0.19 & & & & 0.08 & \\
\hline Higher education degree & 0.13 & * & 0.19 & & & & 0.13 & $* *$ \\
\hline $\log (\text { age-13) })^{\mathrm{a}}$ & 5.41 & ** & 4.32 & *** & 5.42 & ** & 5.08 & ** \\
\hline Log $(45 \text {-age })^{\mathrm{a}}$ & 2.55 & $* *$ & 2.14 & $*$ & 2.31 & $* *$ & 2.36 & $*$ \\
\hline $\begin{array}{l}\text { Regional origin eastern (ref.: } \\
\text { western) }\end{array}$ & & & & & 0.73 & $* *$ & 0.46 & $* *$ \\
\hline East $\times$ cohort 1993 & & & & & 0.41 & & 0.02 & \\
\hline Constant & -25.03 & $* *$ & -20.41 & $* *$ & -24.42 & $* *$ & -23.57 & $* *$ \\
\hline Cases & 9074 & & 2284 & & 11,398 & & 11,358 & \\
\hline Events & 2979 & & 1032 & & 4022 & & 4011 & \\
\hline Log likelihood initial model & -4650 & & -914 & & -5645 & & -5623 & \\
\hline Log likelihood final model & -2146 & & -312 & & -2700 & & -2473 & \\
\hline
\end{tabular}

Source: DZHW graduate surveys 1993-2005

Note: ${ }^{a}$ time-varying; $* \mathrm{p}<.05, * * \mathrm{p}<0.01$

According to the multivariate analysis (Table 10.1, Model I) the cohort differences for western German graduates are similar to those estimated by survival analysis (only the difference between the 1993 and 1997 cohort is not significant). However, the marked differences between the eastern German graduates in the 1993 
cohort and those in the later cohorts disappear (Table 10.1, Model II). This result is attributable to the conditional effect of studying which varied in eastern Germany with the year of graduation. While this institution effect is highly significant in the west and has the expected negative sign-indicating that the inclination to make the transition to motherhood is significantly reduced during a period of study - a similar effect in the east is observable only in the more recent graduate cohorts. As indicated by the highly positive interaction effect "in first degree course $\times$ cohort 1993", the institution effect among those in the 1993 graduate cohort - the majority of whom began their studies before German reunification-did not play a role. The second institution effect, which refers to a further phase of education after the first degree, is significant and negative for all eastern German graduates, but is less pronounced than among western German graduates.

As anticipated, graduates from different fields of study have very different family formation rates. Graduates in western and eastern Germany who earned a teaching or a medical degree, or a degree in social work awarded by a university of applied sciences, tend to make the transition to motherhood far sooner than graduates in other subjects. This result, which is in line with analyses of other datasets for Germany (Maul 2012) and for other countries (synoptic overview in Maul 2012, see also Neyer et al. in this volume), is found even without controlling for the birthpostponing effect of undertaking a further phase of education.

As we also expected, graduates of law, business, and economics have significantly lower transition rates. However, in western Germany the reduced inclination of these graduates to form a family exists only for the period of study for the first degree (see the negative and significant interaction effect "in first degree course $x$ law/business/economics"). Once they have completed their studies, western German law, business and economics graduates give birth to their first child only marginally later than graduates of the study programmes grouped together in the reference category. However, the difference to graduates who studied social subjects remained significant. By contrast, among eastern German law, business, and economics graduates, the transition rates are a little higher during the period of study for the first degree, and are significantly lower afterwards. In this case as well, the family formation rates are much lower than among graduates of social subjects.

Contrary to our assumption that, given their greater career resources and aspirations, women from a family with a higher social status would postpone family formation to a greater extent, parents' qualifications actually produce only a slight and sometimes even an opposite effect among higher education graduates. For example, western German graduates born to parents with a higher education degree make the transition to motherhood slightly, but still significantly more often than other western German women.

In keeping with all of the other known studies, the age of higher education graduates has the expected non-monotonic effect on the family formation rate. This age dependence reflects a conglomeration of different factors which influence the timing of family formation. Apart from the biological limits of fertility, they include social and milieu-specific age conventions, the current state of career development (more on this below), and, finally, psychological preconditions. Personal maturity 
appears to be a major prerequisite for motherhood: for example, the reasons students give for not starting a family while studying include that they are "too young and inexperienced, and were still developing their personalities or finding their way in life", and are thus not yet "ready or able to accept the responsibility for a child" (Middendorff 2003: 22). The increasing participation in education may therefore have triggered an increasing postponement of family formation, not only because it is considered difficult or inopportune to have a baby while in education and training, but also because prolonged participation in education has contributed to an extension of adolescence.

Although the survival analyses detected an east-west difference in family formation among higher education graduates as well, they also showed that a partial alignment has taken place over time. This finding is confirmed by the multivariate analyses: higher education graduates from the eastern German federal states, even if they belong to the younger graduate cohorts (from 1997), continue to have their first child earlier than western German graduates (Table 10.1, Model III). The fertility behaviour of eastern and western German degree holders has, however, converged. As indicated by the positive interaction effect "east $\times$ cohort 1993", the east-west difference in the transition rate is significantly larger in the older graduate cohorts than in the more recent ones. To a large extent, however, this convergence is a result of a marked decrease in the inclination of women to make the transition to motherhood while in education. This insight was provided by the fourth estimation model, which took into account the fact that in the east the institution effect varies with the year of graduation, and therefore included the interaction "first degree $\times$ east $\times$ cohort 1993". In this model, the interaction effect "east $\times$ cohort 1993" was no longer significant. Once they had completed their studies, eastern German graduates belonging to the more recent graduate cohorts were not making the transition to motherhood any later than women in the older cohorts. Although the east-west effect itself was smaller in the combined model that included all of the variables (Table 10.1, Model IV), it remained significant at the one per cent level.

\subsubsection{Family Formation and Employment History}

Theoretical approaches which refer to one of the rational choice models of behaviour, and which posit that parenthood can be a strategy for reducing uncertainty, have suggested that because of economic uncertainty or lower opportunity costs associated with family formation, women with fewer career resources and opportunities have their first child earlier than women with good career and income prospects. This hypothesis is supported by our finding that the women in the sample of the western German degree holders who experienced downward occupational mobility or were unable to obtain a permanent employment contract were more inclined to start a family (Table 10.2, Model I). Also in line with these theoretical predictions is the finding that the transition to motherhood is delayed among women who have a very high professional position (level 6 on the career ladder). On the 
other hand, upwardly mobile women do not have lower transition rates than female higher education graduates with lateral employment paths. Interruptions of employment and a career start which do not match the graduates' level of education did not accelerate family formation. Women who have a low professional position do not have their first child earlier than those who were employed in a higher position. These findings tend to support the hypothesis that the reliability of both career and economic prospects is a precondition of motherhood for highly qualified women (Kreyenfeld (2010) reached a similar conclusion).

Even after the characteristics of the employment history and professional situation are controlled for, the analysis indicate that the 2001 and 2005 graduate cohorts had their first child a little bit later than the 1997 cohort; however, the effect was not always significant.

The overall effect of economic inactivity on the timing of the first birth is negative: employed women are the first to make the transition to motherhood. When looking at the reasons for interruptions in employment, we find that participation in education is the most important factor in the west. Among female higher education graduates from eastern Germany, however, this "institution effect" is considerably and significantly weaker. This is indicated by the interaction effect "further phase of education $\times$ east Germany" estimated in the combined model (Table 10.2, Model III). For eastern German graduates, participation in education do not delay family formation to the same extent as it do among western German women. The transition to motherhood is similarly unlikely to have taken place in the transitional phase between graduation and starting a first job or a further phase of education. Relatively brief periods of economic inactivity for other reasons do not significantly reduce the inclination to form a family, but prolonged interruptions in employment for other reasons have a strong negative effect.

It has been shown that the transition to fatherhood is not affected by uncertainty in the employment biography arising from temporary employment contracts (Tölke 2005; Schmitt 2008). For highly qualified women, the situation appears to be different. The transition to motherhood is fostered by both very insecure employment conditions (no permanent employment contract throughout the entire observation period) and an early stabilisation of the employment situation.

Our analysis shows that the sooner graduates from both western and eastern Germany are in permanent employment, the more likely they are to start a family. Family formation is also positively influenced by the attainment of an intermediate professional position. By contrast, self-employment, which generally entails a substantial time commitment and - at least in the initial start-up period-biographical uncertainties, exert a negative influence.

Furthermore, the transition rate is lower among western German women who are working full time 9 months before giving birth, possibly because of high opportunity costs. In the eastern German federal states, however, the number of hours female higher education graduates were working does not play a significant role. Compared with western German graduates, the family formation behaviour of eastern German women was less dependent on their career path and employment pattern. The east-west effect estimated in the combined model (Table 10.2, Modell III) 
Table 10.2 The transition to motherhood after graduation in different cohorts: the effect of career development (exponential rate models), beta-coefficients

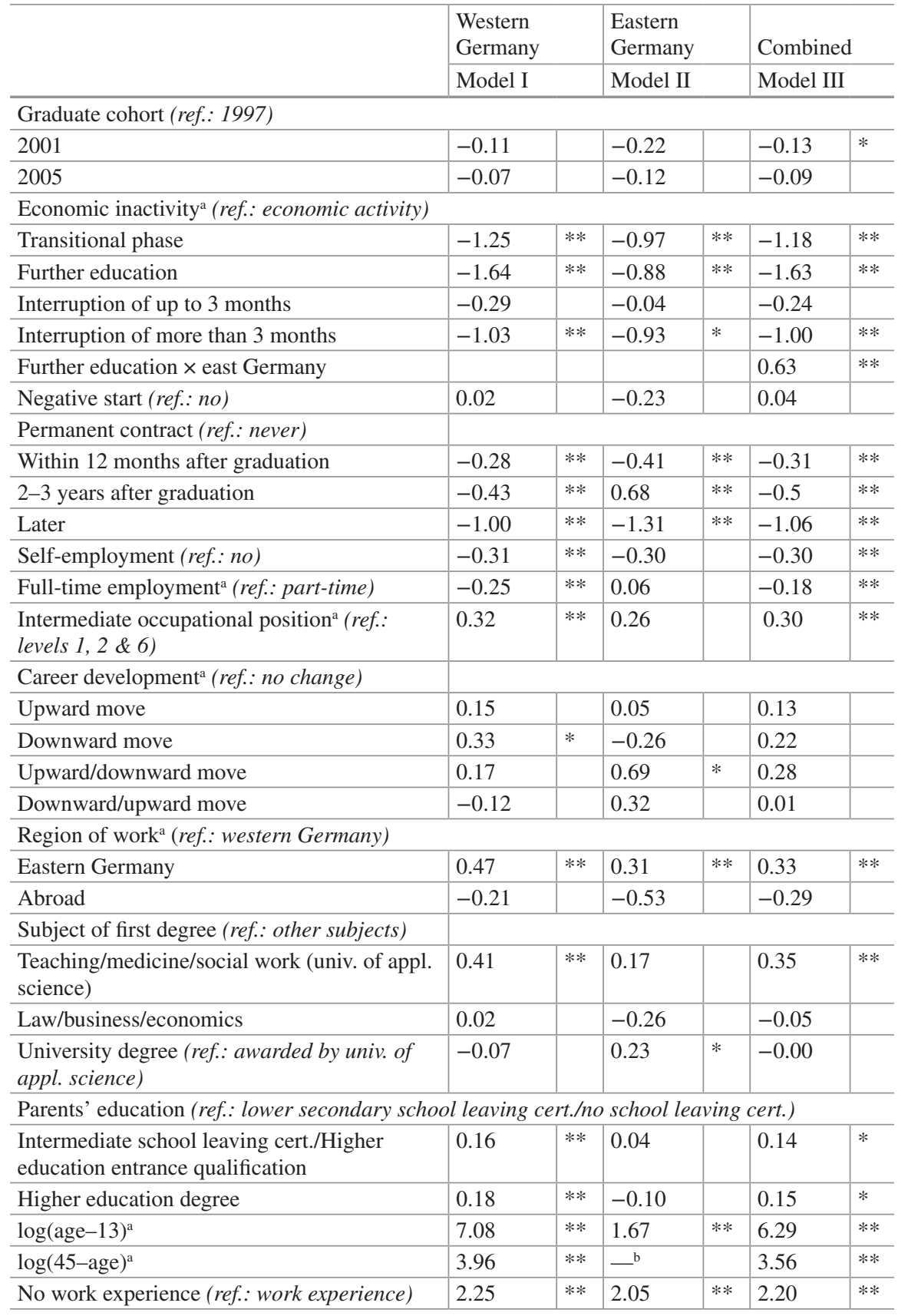


Table 10.2 (continued)

\begin{tabular}{|c|c|c|c|c|c|c|}
\hline \multirow{3}{*}{$\begin{array}{l} \\
\begin{array}{l}\text { Regional origin eastern Germany (ref.: } \\
\text { western Germany) }\end{array}\end{array}$} & \multicolumn{2}{|l|}{\begin{tabular}{|l|} 
Western \\
Germany
\end{tabular}} & \multicolumn{2}{|l|}{$\begin{array}{l}\text { Eastern } \\
\text { Germany }\end{array}$} & \multicolumn{2}{|c|}{ Combined } \\
\hline & \multicolumn{2}{|l|}{ Model I } & \multicolumn{2}{|l|}{ Model II } & \multicolumn{2}{|c|}{ Model III } \\
\hline & & & & & 0.42 & $* *$ \\
\hline Constant & -35.75 & $* *$ & -9.24 & $*$ & -32.41 & $* *$ \\
\hline Cases & 6470 & & 1866 & & 8336 & \\
\hline Events & 1744 & & 747 & & 2491 & \\
\hline Log likelihood initial model & -4939 & & -1218 & & -6198 & \\
\hline Log likelihood final model & -4168 & & -1021 & & -5205 & \\
\hline
\end{tabular}

Source: DZHW graduate surveys 1997-2005

Note: ${ }^{\text {a }}$ time-varying, ${ }^{\mathrm{b}}$ not useful to estimate because of the small age range observed; $* \mathrm{p}<.05$; $* * \mathrm{p}<.01$

is significant even after controlling for all of the included career characteristics. In other words, the transition to motherhood among the female graduates from eastern Germany continues to be more natural and less dependent on the fulfilment of preconditions than among their western German counterparts.

In terms of career development, the effects of downward mobility are most notable: compared with other mobility patterns, western German graduates make the transition to motherhood much earlier if they experience a downward move without a subsequent or prior upward move. Among eastern German graduates, the transition to motherhood is more likely when a downward move was preceded by an upward move.

Finally, we comment on the region of employment. While being employed abroad tends to reduce the transition rate, the differences between working abroad and working in western Germany are not significant. For both eastern and western German female higher education graduates, economic activity in eastern Germany increase the inclination to start a family. It appears plausible that this finding is related to the more favourable opportunity structures in the east, especially the greater availability of public childcare.

Our empirical findings on the association among female higher education graduates in Germany between fertility behaviour on the one hand and the occupational career and the employment situation on the other are inconsistent with several theoretical explanations. They are not in line with arguments originating from family economics, the claim that family formation reduces uncertainty, or the argument that family formation depends on secure career and economic prospects. Instead, the results suggest that there is a more differentiated explanation for fertility behaviour: in the years immediately after graduating, women tend to focus on consolidating their career and securing their occupational and economic positions. In the current conditions, career-minded women—and, as a general rule, female graduates are career-oriented-risk the long-term impairment of their employment opportunities if they have a child before embarking on a career or entering permanent employment. In order to establish a career path that can be taken up again after family 
formation, women hold off on motherhood until they have attained a stable employment position. Only if there appears to be little or no prospect of consolidating and stabilising their employment situation-or if it seems unlikely that further postponement of family formation will result in the desired employment security-will graduates make the transition to motherhood more frequently and quickly.

\subsection{Summary and Discussion}

Adopting a multi-level life-course perspective and using quantitative analyses, this paper has examined the relationship between the fertility behaviour of highly qualified women and their educational and employment histories, as well as their current employment status and career situation.

Reflecting the general trend, we found that female higher education graduates were delaying the birth of their first child to an increasing extent. At first glance, the results for the 2009 graduate cohort, which suggest a considerably lower propensity to make the transition motherhood, were particularly striking. It is, however, important to note that the analyses were based on a very short observation period, and that the imprecise process time, which was measured in years, resulted in an underestimation of the family formation rate.

While we found that differences between the family formation processes of eastern and western German women persist, we also observed a convergence. However, the approximation was solely attributable to the behaviour of eastern German graduates who entered higher education after German reunification, and who were much less likely to have had their first child while enrolled in higher education. This institution effect played only a marginal role among eastern German higher education graduates who began their studies during the GDR era. However, for subsequent generations of students it appears to be as relevant as for western German students. As a consequence of this relationship of interdependence and mutual exclusion between participation in education and family formation, highly qualified women are not starting to plan a family until they reach an age when the most biologically opportune time for the transition to motherhood has already ended.

To some extent, the sharp decline in the inclination of eastern German students to start a family before graduating can be attributed to the increased opportunity costs of family formation while in education. As the forms of support provided to students with children in the GDR have been eliminated, and the financing of participation in higher education has become less secure, many student parents in eastern Germany now also have to shoulder not only the double burden of attending university and childcare, but often the triple burden of studying, raising a child, and having a job. The increased uncertainty of the career prospects of higher education graduates is likely another contributor to the cautious attitude towards starting a family among eastern German undergraduates. As they are no longer guaranteed a job upon graduating, they must prepare for the possibility of unemployment. Thus, students face an exacerbated resource problem which threatens the economic basis of family formation. 
Despite the greater uncertainty of their career prospects, graduates from eastern Germany still make the transition to motherhood more quickly and frequently than western German higher education graduates. This finding can be explained by the persistence of the eastern German gender culture, in which working mothers and institutional childcare are viewed as normal, and by the greater availability of childcare in eastern Germany.

Qualitative analyses have shown that women's deliberations concerning family formation are shaped to a large extent by this question of how to reconcile work and family. They have also described how this compatibility problem can give rise to an ambivalent attitude among career-focused women, and ultimately to fertility postponement (Kühn 2004). A solution to the reconciliation issue is complicated not only by inadequate childcare services and the expectation that highly qualified employees will be flexible and mobile, but also by the prevailing labour market conditions governing career development. Part-time employment has negative connotations, and is associated with a lack of commitment, availability, and motivation; as well as by a lack of professional or career ambition. It is not surprising, therefore, that women with elevated professional aspirations or abundant career resources postpone family formation, or even forego having children; or that, conversely, women reduce their career development efforts in anticipation of the transition to motherhood. This relationship between family formation on the one hand and professional ambition and career development and resources on the other was also reflected to some extent in our results on the fertility decisions of female higher education graduates. However, our findings also pointed to another, more important aspect of the timing of family formation: namely, the issue of career consolidation and the establishment of stable professional prospects. A woman's decision about if and when to make the transition to motherhood essentially depends on whether she has achieved a stable employment status and has been able to accumulate sufficient work experience. Only if these conditions are met is she likely to assume that her career ambitions can again be pursued after having a child. On the other hand, attention may turn to family formation if over a prolonged period of time a women has had negative experiences in the labour market which indicate that her outlook for attaining stable employment is poor, and that attaining a secure and challenging occupation is likely to remain out of reach. Unless a highly qualified woman clearly prioritises having a family, the tendencies mentioned above, together with participation in further qualification phases, may mean that family formation will not become a focal point of her biographical reflections until several years after graduation.

It remains to be seen whether family policy measures that have been adopted will have the desired impact on female degree holders as well, motivating and allowing them to have children earlier and more often. Given the very significant role career consolidation plays in shaping the fertility behaviour of women (and men), and the growing prevalence of fixed-term employment contracts (Rehn et al. 2011), a sceptical view of the ability of family policy measures alone to halt or even reverse the trend towards the progressive postponement of family formation appears to be justified. 


\section{Literature}

Blossfeld, H.-P., \& Rohwer, G. (1995). West Germany. In H.-P. Blossfeld (Ed.), The new role of women: Family formation in modern societies (pp. 56-76). Boulder: Westview Press.

Born, C. (2001). Modernisierungsgap und Wandel. Angleichung geschlechtsspezifischer Lebensführungen? In C. Born \& H. Krüger (Eds.), Individualisierung und Verflechtung. Geschlecht und Generation im deutschen Lebenslaufregime (pp. 29-53). Weinheim/München: Juventa.

Brose, N. (2008). Entscheidung unter Unsicherheit - Familiengründung und -erweiterung im Erwerbsverlauf. Kölner Zeitschrift für Soziologie und Sozialpsychologie, 60, 34-56.

Buhr, P., Huinink, J., Boehnke, M., \& Maul, K. (2011). Kinder oder keine? Institutionelle Rahmenbedingungen und biographische Voraussetzungen für die Familiengründung und -erweiterung in Ost- und Westdeutschland. In J. Brüderl, L. Castiglioni, \& N. Schumann (Eds.), Partnerschaft, Fertilität und intergenerationale Beziehungen. Ergebnisse der ersten Welle des Beziehungs- und Familienpanels (pp. 175-201). Würzburg: Ergon.

Bujard, M. (2011). Familienpolitik und Geburtenrate. Ein internationaler Vergleich. Berlin: BMFSFJ.

Dorbritz, J., \& Ruckdeschel, K. (2013). Kinderlosigkeit - differenzierte Analysen und europäische Vergleich. In D. Konietzka \& M. Kreyenfeld (Eds.), Ein Leben ohne Kinder. Ausmaß, Strukturen und Ursachen von Kinderlosigkeit (2nd ed., pp. 253-278). Wiesbaden: Springer VS.

Dornseiff, J.-M., \& Sackmann, R. (2003). Familien-, Erwerbs- und Fertilitätsdynamiken in Ost- und Westdeutschland. In W. Bien \& J. H. Marbach (Eds.), Partnerschaft und Familiengründung. Ergebnisse der dritten Welle des Familien-Survey (pp. 309-348). Opladen: Leske + Budrich.

Eckhard, J., \& Klein, T. (2012). Rahmenbedingungen, Motive und die Realisierung von Kinderwünschen. Erkenntnisse aus dem westdeutschen Familiensurvey. In H. Bertram \& M. Bujard (Eds.), Zeit, Geld, Infrastruktur - zur Zukunft der Familienpolitik (pp. 231-251). Baden-Baden: Nomos.

Friedman, D., Hechter, M., \& Kanazawa, S. (1994). A theory of the value of children. Demography, $31,375-401$.

Gebel, M., \& Giesecke, J. (2009). Ökonomische Unsicherheit und Fertilität. Die Wirkung von Beschäftigungsunsicherheit und Arbeitslosigkeit auf die Familiengründung in Ost- und Westdeutschland. Zeitschrift für Soziologie, 38, 399-417.

Goldstein, J., Kreyenfeld, M., Huinink, J., Konietzka, D., \& Trappe, H. (2010). Familie und Partnerschaft in Ost- und Westdeutschland. Ergebnisse im Rahmen des Projektes „Demographic Differences in Life Course Dynamics in Eastern and Western Germany“. Rostock: Max-Planck-Institut für demografische Forschung. http://www.demogr.mpg.de/ publicationsIfiles|3988_1287680847_1_familie_und_partnerschaft_ost_west.pdf. Accessed 8 Aug 2014.

Heine, C., Spangenberg, H., Schreiber, J., \& Sommer, D. (2005). Studienanfänger in den Wintersemestern 2003/04 und 2004/05. Hannover: HIS.

Hemsing, W. (2001). Berufserfolg im Lebenslauf. Der Einfluss von Humankapitalinvestitionen, privaten Bindungen und Arbeitsmarktstrukturen aufden Berufserfolg ehemaliger Gymnasiasten . Doctoral Dissertation, Universität Köln. http://kups.ub.uni-koeln.de/684/1/11w1431.pdf. Accessed 7 Aug 2014.

Herlyn, I., Krüger, D., \& Heinzelmann, C. (2002). Späte erste Mutterschaft - erste empirische Befunde. In N. F. Schneider \& H. Matthias-Bleck (Eds.), Elternschaft heute. Gesellschaftliche Rahmenbedingungen und individuelle Gestaltungsaufgaben (Sonderheft zur Zeitschrift für Familienforschung, Vol. 2, pp. 121-162). Opladen: Leske + Budrich. 
Heublein, U., Hutzsch, C., Schreiber, J., Sommer, D., \& Besuch, G. (2010). Ergebnisse einer bundesweiten Befragung von Exmatrikulierten des Studienjahres 2007/08. Ursachen des Studienabbruchs in Bachelor- und in herkömmlichen Studiengängen. Hannover: HIS.

Huinink, J. (1995). Warum noch Familie? Zur Attraktivität von Partnerschaft und Elternschaft in unserer Gesellschaft. Frankfurt/Main: Campus.

Huinink, J. (2000). Bildung und Familienentwicklung im Lebensverlauf. Zeitschrift für Erziehungswissenschaft, 3, 209-227.

Kreyenfeld, M. (2010). Uncertainties in female employment careers and the postponement of parenthood in Germany. European Sociological Review, 26, 351-366.

Kühn, T. (2004). Berufsbiografie und Familiengründung. Biografiegestaltung junger Erwachsener nach Abschluss der Berufsausbildung. Wiesbaden: VS Verlag für Sozialwissenschaften.

Leszczensky, M., \& Filaretow, B. (1990). Hochschulstudium in der DDR. Statistischer Überblick. Hannover: HIS.

Levy, R. (1996). Zur Institutionalisierung von Lebensläufen. Ein theoretischer Bezugsrahmen. In J. Behrens \& W. Voges (Eds.), Kritische Übergänge. Statuspassagen und sozialpolitische Institutionalisierung (pp. 73-113). Frankfurt/Main: Campus.

Maul, K. (2012). Der Einfluss der beruflichen Tätigkeit auf die Familiengründung. Würzburg: Ergon.

Middendorff, E. (2003). Kinder eingeplant? Lebensentwürfe Studierender und ihre Einstellung zum Studium mit Kind (HIS-Kurzinformation A, Vol. 4). Hannover: HIS.

Middendorff, E. (2008). Studieren mit Kind. Ergebnisse der 18. Sozialerhebung des Deutschen Studentenwerks durchgeführt durch HIS Hochschul-Informations-System. Bonn: Bundesministerium für Bildung und Forschung.

Passet, J. (2011). Kinderlosigkeit im Lebensverlauf: Wie wichtig ist das Lebensziel, Kinder zu bekommen, im Vergleich mit anderen Lebenszielen? Bevölkerungsforschung Aktuell, 32, $7-11$.

Pfau-Effinger, B. (1998). Arbeitsmarkt- und Familiendynamik in Europa - Theoretische Grundlagen der vergleichenden Analyse. In B. Geissler, F. Maier, \& B. Pfau-Effinger (Eds.), FrauenArbeitsMarkt. Der Beitrag der Frauenforschung zur sozio-ökonomischen Theorieentwicklung (pp. 177-194). Berlin: Edition sigma.

Pötzsch, O. (2010). Cohort fertility: A comparison of the results of the official birth statistics and of the Microcensus survey 2008. Comparative Population Studies - Zeitschrift für Bevölkerungswissenschaft, 35, 185-204.

Rehn, T., Brandt, G., Fabian, G., \& Briedis, K. (2011). Hochschulabschlüsse im Umbruch. Studium und Übergang von Absolventinnen und Absolventen reformierter und traditioneller Studiengänge des Jahrgangs 2009. Hannover: HIS.

Schaeper, H., \& Kühn, T. (2000). Zur Rationalität familialer Entscheidungsprozesse am Beispiel des Zusammenhangs zwischen Berufsbiographie und Familiengründung. In W. R. Heinz (Ed.), Übergänge. Individualisierung, Flexibilisierung und Institutionalisierung des Lebensverlaufs (Zeitschrift für Soziologie der Erziehung und Sozialisation, Beiheft 3, pp. 124-145). Weinheim: Juventa.

Schaeper, H., Grotheer, M., \& Brandt, G. (2013). Kinderlosigkeit - differenzierte Analysen und europäische Vergleich. In D. Konietzka \& M. Kreyenfeld (Eds.), Ein Leben ohne Kinder. Ausmaß, Strukturen und Ursachen von Kinderlosigkeit (2nd ed., pp. 47-80). Wiesbaden: Springer VS.

Schmitt, C. (2008). Labour market integration and the transition to parenthood. A comparison of Germany and the UK. (SOEPpapers on Multidisciplinary Panel Data Research No. 119). Berlin: Deutsches Institut für Wirtschaftsforschung. http://www.diw.de/documents/publikationen/73/diw_01.c.88337.de/diw_sp0119.pdf. Accessed 8 Aug 2014.

Schröder, J., \& Brüderl, J. (2008). Der Effekt der Erwerbstätigkeit von Frauen auf die Fertilität: Kausalität oder Selbstselektion? Zeitschrift für Soziologie, 37, 117-136. 
Schütz, A. (1971). Das Wählen zwischen Handlungsentwürfen. In A. Schütz (Ed.), Gesammelte Aufsätze, Bd. 1: Das Problem der sozialen Wirklichkeit (pp. 77-110). Den Haag: Nijhoff. English edition: Schütz, A. (1962). Choosing among projects of action. In A. Schütz (Ed.), Collected papers 1: The problem of social reality. The Hague: Nijhoff.

Tölke, A. (2005). Die Bedeutung von Herkunftsfamilie, Berufsbiografie und Partnerschaften für den Übergang zur Ehe und Vaterschaft. In A. Tölke \& K. Hank (Eds.), Männer - das, vernachlässigte 'Geschlecht in der Familienforschung (pp. 98-126). Wiesbaden: VS Verlag für Sozialwissenschaften.

Open Access This chapter is distributed under the terms of the Creative Commons Attribution 4.0 International License (http://creativecommons.org/licenses/by/4.0/), which permits use, duplication, adaptation, distribution and reproduction in any medium or format, as long as you give appropriate credit to the original author(s) and the source, provide a link to the Creative Commons license and indicate if changes were made.

The images or other third party material in this chapter are included in the work's Creative Commons license, unless indicated otherwise in the credit line; if such material is not included in the work's Creative Commons license and the respective action is not permitted by statutory regulation, users will need to obtain permission from the license holder to duplicate, adapt or reproduce the material.

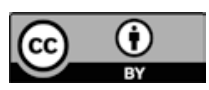

